\title{
Lektorok, 2020
}

\section{Reviewers, 2020}

2020-ban 78 lektorral dolgoztunk együtt, akik szakértelmükkel segítették a szerkesztőséget és a szerzőket abban, hogy a Tér és Társadalomban színvonalas tanulmányok jelenhessenek meg. Ezúton is köszönjük munkájukat! 2020-ban lektoraink voltak:

$\begin{array}{lll}\text { Ács Pongrác } & \text { Gál Zoltán } & \text { Németh Kornél } \\ \text { Albert Fruzsina } & \text { Gulyásné Kerekes Rita } & \text { Paár Dávid } \\ \text { Ásványi Katalin } & \text { Gyáni Gábor } & \text { Pálné Kovács Ilona } \\ \text { Bajmócy Zoltán } & \text { Győri Péter } & \text { Pálvölgyi Tamás } \\ \text { Balogh Péter } & \text { Gyurgyák László } & \text { Pámer Zoltán } \\ \text { Balogi Anna } & \text { Hamza Eszter } & \text { Perger Éva } \\ \text { Bálint Lajos } & \text { Hegedús József } & \text { Pénzes János } \\ \text { Berger Viktor } & \text { Horváth M. Tamás } & \text { Péti Márton } \\ \text { Boros Lajos } & \text { Huszár Ákos } & \text { Rechnitzer János } \\ \text { Bugya Titusz } & \text { Izsák Éva } & \text { Rédei Mária } \\ \text { Czibere Ibolya } & \text { Jóna László } & \text { Rusinné Fedor Anita } \\ \text { Csapó János } & \text { Kádár Bálint } & \text { Scharle Ágota } \\ \text { Csata Zsombor } & \text { Kiss Julianna } & \text { Schuchmann Júlia } \\ \text { Csicsmann László } & \text { Koós Bálint } & \text { Sipos András } \\ \text { Csomós György } & \text { Kulcsár László } & \text { Szabó Dorottya } \\ \text { Dőry Tibor } & \text { Kuttor Dániel } & \text { Szabó Pál } \\ \text { Dusek Tamás } & \text { Lengyel Imre } & \text { Szörényiné Kukorelli Irén } \\ \text { Erdős Katalin } & \text { Lipták Katalin } & \text { Tátrai Patrik } \\ \text { Erdősi Ferenc } & \text { Lux Gábor } & \text { Teller Nóra } \\ \text { Faragó László } & \text { Málovics György } & \text { Timár Judit } \\ \text { Farkas Jenő Zsolt } & \text { Megyesi Boldizsár } & \text { Toma Stefánia } \\ \text { Farkas Zsombor } & \text { Messing Vera } & \text { Tomay Kyra } \\ \text { Fehér Boróka } & \text { Mezei Zsuzsanna Cecília } & \text { Tóth Balázs István } \\ \text { Fleischer Tamás } & \text { Molnár Ernő } & \text { Varga Júlia } \\ \text { Fosztó László } & \text { Nagy Gábor } & \text { Vas Zsófia } \\ \text { Füzi Anita } & \text { Nagy Terézia } & \text { Zsibók Zsuzsanna } \\ & & \end{array}$

